\section{CEREBROVASCULAR ACCIDENTS IN NIGERIANS: A STUDY OF 348 PATIENTS}

By

DR. B. O. OSUNTOKUN,

Consultant Physician and Senior Lecturer in Neurology, Department of Psychiatry and Neurology

PROFESSOR E. L. ODEKU, M.D. (HOWARD), D.A.B...S.S.

Fonsultant Neurosurgeon and Professor of Surgery,

Department of Surgery

and

DR. R.B.A. ADELOYE, M.B., B.S. (LOND.), M.R.C.P. (EDIN.), F.R.C.S.

Consultant Neurosurgeon and Lecturer, Department of Surgery

Cerebrovascular accident (CVA) is one of the major causes of sudden death. In addition it has a high morbidity being responsible for many patients with incapacitating neurological deficit. Until recently there was scanty information on CVA in Africans, and some held that cerebrovascular disease (CVD) like coronary artery disease is rare in the African. Humphries (1957) for instance states that in 14 years work among natives of South, Central and West Africa, he saw few instances of CVD either due to hemorrhage or infarcation. It has since been shown that CVD is not uncommon in the Bantus in South and East Africa (LAURE and WOODS, 1958, STRONG et al., 1959, WALKER, 1963), and in the Senegalese in West Africa (COLLOMB et al., 1966). It is important to establish the pattern of CVD in the various African races and the difference, if any, from that described in the more developed countries. This paper describes our experience and findings in Nigerian patients seen at the University College Hospital, (UCH) Ibadan, between 1957 and 1968. The UCH is a 500-bed hospital of the University of Ibadan. It is situated in Ibadan, which has a population of 750,000 - the largest Negro city in the world, The majority of the inhabitants of Ibadan is formed by the Yorubas, who also constitute about 90 per cent of the patients seen in the hospital. The rest of the patients come from all parts of Nigeria.

\section{Material and methods}

In this paper, cerebrovascular accidents (CVA) refer to cerebral thrombosis, intracerebral hemorrhage and embolism as defined by the National Institute of Neurological Diseases and Blindness (1958).

Three hundred and forty-eight patients who suffered from CVA and were seen at the UCH., Ibadan from 1957 to 1968 form the basis of the study. Eighty per cent of the patients have been seen in the last 6 years (1962-1968). (In 1962, a Neurosurgical Unit was established at UCH., Ibadan followed by a Neurology Unit in 1964).
Investigations of the patients included: determination of haemtological indices including haemoglobin electrophoretic fractionation; cerebrospinal fluid (CSF) examination; serum urea and electrolyte; serum protein and electrophoretic fractionation; serum cholesterol (by the method of SEARCY and BERGQUIST, 1960); plain radiographs of chest, cervical spine and skull; and electrocardiographic (ECG) examination. In the last three years, we have carried out glucose tolerance tests without and with steroid priming (as described by JACKSON 1961) on patients with thrombotic CVA and primary intracerebral haemorrhage a week after admission into hospital. In appropriate cases carotid angiography and arch aorto-graphy were done, and so was lumbar pneumo-encephalography in a few patients especially where angiographic examination was normal.

Hypertension was diagnosed when a diastolic blood pressure of $100 \mathrm{~mm}$. Hg. or more was sustained for more than a week after admission, or if death occurred within one week of admission, if there was clinical and ECG evidence of hypertensive disease.

\section{Diagnosis}

It is not always possible, on clinical findings alone to distinguish confidently between intracerebral haemorrhage and cerebral infarcation despite the application of the criteria painstakingly enumerated by ARING and MERRITT (1935) on the basis of their clinicopathological study. For example DALSGAARDNIELSEN (1956) found that the clinical diagnosis of cerebral haemorrhage in 239 cases was confirmed at autopsy in only 155 (65 per cent) and that the clinical diagnosis of cerebral arterial thromboembolic occlusion in 139 cases was confirmed in only 81 (58 per cent). HEASMAN and LIPWORTH (1966) reporting on 10,000 death certificates confirmed by autopsy found that clinical diagnosis of cerebral haemorrhage was confirmed in only 57 per cent of the cases. What is more every series of unselected strokes includes about 5 per cent of cases which ultimately proved to be due to a cerebral tumour and this at times may be a meningiomic (MARSHALL, 1967). Subdural haematoma may present as a stroke (BULL, 1958). Hence ancillary methods are of great importance in achieving the correct pathological diagnosis. Angiography is the most important in this respect, for not only will it localize the lesion and delineate the pathology, but may reveal a lesion sometimes previously unsuspected clinically and sometimes amenable to surgery (BULL et al. 1960). The basis of our diagnosis was the criteria given by the National Institute of Neurological Disease and Blindness (1958), and by OSUNTOKUN et al. (1969) for the diagnosis of non-embolic ischaemic cerebrovascular disease, and on further investigations.

\section{Results}

Incidence

Table 1 shows the types of CVA seen. Non-embolic ischaemic cerebrovascular disease (NEICVD) is by far 
the commonest and constitute 67.5 per cent of CVA and 49.8 per cent of all cerebrovascular diseases as seen in Nigerians in UCH, Ibadan (Table II). In the eleven-year period under consideration, in the U.C.H., Ibadan, 560 patients with epilepsy, 324 patients with nutritional neuropathies, 74 patients with Parkinsonism, 60 patients with motor neurone disease and 827 patients with diabetes mellitus were seen. At least 200,000 patients were seen in the various departments and wards of the hospital.

Table I. Cerebrovascular accident in Nigerians, University College Hospital, Ibadan, 1957-1968

\begin{tabular}{|l|l|l|}
\hline & $\begin{array}{l}\text { No. of } \\
\text { patients }\end{array}$ & $\begin{array}{l}\% \text { of } \\
\text { total }\end{array}$ \\
\hline $\begin{array}{l}\text { Non-embolic ischaemic disease } \\
\text { Cerebral haemorrhage }\end{array}$ & 235 & 67.5 \\
Embolic ischaemic disease & 21 & 6.1 \\
\hline
\end{tabular}

Table II. Cerebrovascular disease in Nigerians, University College Hospital, Ibadan, 1957-1968

\begin{tabular}{|c|c|c|}
\hline & $\begin{array}{l}\text { No. of } \\
\text { Patients }\end{array}$ & $\begin{array}{l}0 \% \\
\text { of total } \\
\end{array}$ \\
\hline $\begin{array}{l}\text { Non-embolic ischaemic } \\
\text { cerebrovascular }\end{array}$ & 235 & 49.8 \\
\hline disease & 92 & 19.5 \\
\hline Cerebral haemorrhage & 57 & 12.1 \\
\hline Primary subarachnoid & & \\
\hline haemorrhage & 39 & 8.3 \\
\hline Subdural haematoma & 28 & 5.9 \\
\hline Hypertensive encephalopathy & & \\
\hline $\begin{array}{l}\text { Embolic ischaemic } \\
\text { cerebrovascular disease }\end{array}$ & 21 & 4.4 \\
\hline & 472 & 100 \\
\hline
\end{tabular}

Non-embolic cerebrovascular disease (NEICVD) Sex and age distribution

Table III shows the sex and age distribution in patients with NEICVD. The peak incidence is in the age group 50-59. Sixty and 81 per cent of the patients are over 50 and 40 years respectively. The male to female ratio is 9 to 5 .

Table IV shows the socio-economic status of patients with the various types of CVA compared with other common diseases seen in UCH., Ibadan. Middle and upper class as defined in the series comprise skilled professional men such as doctors, engineers, lawyers, architects etc; first class chiefs or natural rulers, ministers of state, members of parliament, high-ranking civil servants, principals and graduate-teachers in educational institutions, clergymen, wealthy private traders, business executives of industrial organizations; and their wives especially if husbands are monogamous. Patients in the middle and upper social classes constitute a higher percentage of the total number of patients suffering from non-embolic cerebrovascular disease, primary intracerebral haemorrhage, diabetes mellitus and hypertension than in embolic infarcation, epilepsy and amoebiasis.

\section{Predisposing conditions}

Table $\mathrm{V}$ shows the predisposing conditions. Hypertensions and diabetes mellitus are by far the most important predisposing conditions. In 60 per cent of patients,

Table III. Non-embolic ischaemic cerebrovascular disease in Nigerians 1957-1968

Age distribution

\begin{tabular}{|l|cc|cc|cc|c|cc|c|}
\hline Age group in years & $0-9$ & $10-19$ & $20-29$ & $30-39$ & $40-49$ & $50-59$ & $60-69$ & $70-79$ & $80+$ & Total \\
\hline Male & 3 & 1 & 7 & 17 & 28 & 49 & 37 & 10 & 0 & 152 \\
\hline Female & 2 & 1 & 1 & 10 & 26 & 21 & 18 & 2 & 2 & 83 \\
Total & 5 & 2 & 8 & 27 & 54 & 70 & 55 & 12 & 2 & 235 \\
\hline
\end{tabular}


Table IV. Socio-economic dasses in non-embolic cerebral ischaemic dsease compared with other diseases seen in U.C.H, Ibadan.

\begin{tabular}{|l|l|l|}
\hline & $\begin{array}{l}\text { Total } \\
\text { No. }\end{array}$ & $\begin{array}{l}\% \\
\text { constituted } \\
\text { by middle } \\
\text { \&upper } \\
\text { dasses }\end{array}$ \\
\hline $\begin{array}{l}\text { Non-enbolic ischaemic } \\
\text { cerebral disease }\end{array}$ & 235 & 37 \\
$\begin{array}{l}\text { Primary intracerebral } \\
\text { haemorrhage }\end{array}$ & 92 & 30 \\
Embolic infraction & 21 & 5 \\
Diabetes mellitus & 827 & 30 \\
Hypertension & 240 & 16 \\
Amoebiasis & 308 & 9 \\
Epilepsy & 560 & 2 \\
\hline
\end{tabular}

Table V. Non-embolic ischaemic cerebrovascular disea ses in Nigerians, predisposing conditions

\begin{tabular}{|l|l|l|}
\hline & No. & $\%$ \\
\hline $\begin{array}{l}\text { Hyperten sion } \\
\text { Diabetes mellitus }\end{array}$ & $206^{*}$ & 53.6 \\
$\begin{array}{l}\text { Hyperten sion and diabetes } \\
\text { mellitus (incl. 2 "chemical } \\
\text { diabetes") }\end{array}$ & 23 & 8.5 \\
$\begin{array}{l}\text { "Chemical diabetes } \\
\text { Others (include Obesity, } \\
\text { anaemia, dehyd ration, } \\
\text { haemoglobinopa thy, } \\
\text { chronic myeloid leukemia, } \\
\text { syphilis, congestive heart } \\
\text { failure, nephritic syndrome, } \\
\text { pregnancy). }\end{array}$ & 20 & 2.1 \\
$\begin{array}{l}\text { No predisposing conditions } \\
\text { Total }\end{array}$ & 231 & 17.5 \\
\hline
\end{tabular}

*3 of these patients have $\mathrm{Hb} .>18 \mathrm{G}$, and PCV $>55$ but with normal WBC.

hypertension was previously undiagnosed. Table VI shows the severity of diastolic hypertension. Diabetes mellitus had been recognized before the occurrence of CVA in 32 of the 48 patients with diabetes mellitus or diabetes diathesis. Sixteen patients can be said to have "chemical diabetes". The latter group includes 9 patients in whom the standard GTT was diabetic and 7 other patients in whom the steroid-stressed GTT was abnormal. Four patients suffered from cerebrovascular syphilis. In one patient each, a stroke was precipitated by anaemia (Hb. $<20$ per cent) and dehydration following severe gastroenteritis. In one patient each, CVA was associated with chronic myeloid leukaemia and nephrotic syndrome; the latter patient had a serum cholesterol level of $540 \mathrm{mg} / 100 \mathrm{ml}$. In 4 children under 5 years old, haemoglobin sickle cell crisis was associated with hemiplegia. Hypercholesterolaemia in association with gross obesity was present in 3 patients. Three patients were in congestive heart failure, but without any evidence of cardiac valvular disease or of myocardial infarcation.

\section{Transient ischaemic attacks}

The table VII shows the salient features in 23 patients who presented with transient ischaemic attacks (TIAs). The patients were mostly elderly. Fifty per cent were above the age of 60. Intermittently ischaemia in the internal carotid territory was commoner than in the vertebrobasilar territory. The clinical features were as described by williams $(1961,1964)$, williams AND WILSON (1962), BRADSHAW AND MCQUAID (1963), MARSHALL (1964) and in the Nigerian patients in this series are given in details elsewhere (OSHUNTOKUN ET AL., 1969a).

These patients have been followed up for a period of 6 months to 10 years. Eleven of the 15 patients with intermittent ischaemia of the internal carotid territory had progressed to completed strokes. One of the 8 patients with intermittent ischaemia of the vertebrobasilar territory so far followed up for 6 months to 4 years had developed a major stroke 6 months after the first transient ischaemic attack. Six of the younger and moderately hypertensive patients were investigated by angiography, and abnormalities were demonstrable in 5 . In four of the 23 patients severe radiological osteodegenerative changes of cervical spondylosis were demonstrable.

Table VI. Severity of hypertension in 149 hypertensive patients with non-embolic ischaemic disease

\begin{tabular}{|c|l|}
\hline Diastolic BP. in mm. Hg & No. \\
\hline$>120$ & 96 \\
$>130$ & 55 \\
$>140$ & 28 \\
$>150$ & 14 \\
$>160$ & 10 \\
$>170$ & 4 \\
$>180$ & 3 \\
$>190$ & 1 \\
\hline
\end{tabular}


Table VII. Non-embolic ischaemic cerebrovascular disease in $235 \mathrm{Nigerian}$ patients

\begin{tabular}{|c|c|}
\hline \multicolumn{2}{|l|}{ Transient ischaemic attacks } \\
\hline No. of patients & 23 \\
\hline Male : Female ratio & $2.8: 1$ \\
\hline Mean age in years & $56.7( \pm 10.7)$ \\
\hline $\begin{array}{l}\text { Middle and upper socio- } \\
\text { economic classes }\end{array}$ & $70 \%$ \\
\hline Hypertension & 17 \\
\hline $\begin{array}{l}\text { Diabetes mellitus and } \\
\text { hypertension }\end{array}$ & 4 \\
\hline Diabetes mellitus & 1 \\
\hline $\begin{array}{l}\text { Arterial syndromes: } \\
\text { internal carotid } \\
\text { Vertebro-basilar } \\
\text { * T.I.A. } 11 \text { Major strokes } \\
\text { in one month to } 10 \text { years }\end{array}$ & $\begin{array}{l}15 \\
8 \\
12\end{array}$ \\
\hline $\begin{array}{l}\text { Mean serum cholesterol } \\
\text { (in mg./100 ml.) } 208 \pm 57.0\end{array}$ & \\
\hline $\begin{array}{l}\text { Angiography } \\
\text { Internal carotid stenosis } \\
\text { Abnormal arch aortograms } \\
\text { Normal carotid } \\
\text { angiogram }\end{array}$ & $3^{2}$ \\
\hline
\end{tabular}

* Transient ischaemic attacks

\section{Completed strokes}

Table VIII shows that headache is a common prodromal symptom in NEICVD and was present in 15.7 per cent of patients: it was characterized by features of vascular headache. In 13 patients symptoms of left ventricular failure in association with severe hypertension presaged a completed stroke by interval of 1 to 2 weeks: there was no evidence of cardiac valvular lesion, arrthymia of myocardial infarcation.

The mode of onset was gradual, step-like or dispersed in temporal pattern in 88 patients. In 6 of these patients it took 4-6 days before the weakness became maximal and complete. In 104 patients, hemipares or hemiplegia was first noted on waking up from sleep. Twelve patients developed major strokes following a period of TIAs. In 27 other patients, onset of weakness was sudden but without loss of consciousness-arterial occlusion was confirmed by angiography or cerebral infarcation was found at autopsy.

Twenty five patients developed convulsions at the time of the stroke. Only 9 patients were in coma or semicoma on admission, and 7 other patients were severely confused.

The details of the clinical features of thrombotic infarcation and laboratory findings in this series have been given elsewhere (OSUNTOKUN et al., 1969a). Tables IX,X,XI and XII show other relevant physical findings, apart from weakness, sensory loss and hemianopic defects.

Table VIII. Non-embolic ischaemic cerebrovascular disease in 235 Nigerian patients, U.C.H., Ibadan. 1957 - 1968

\begin{tabular}{|l|l|}
\hline Clinical features, prodromal symptoms & No. \\
\hline Headache & 37 \\
Transient ischaemic attacks & 11 \\
$\begin{array}{l}\text { Personality changes } \\
\quad \text { Behavioural aberration, } \\
\text { intellectual deterioration } \\
\quad \text { or dementia) }\end{array}$ & 10 \\
Focal epilepsy & 10 \\
Numbness of hemiplegic distribution & 8 \\
Monocular blindness & 3 \\
Tremor & 2 \\
Vertigo & 3 \\
Diplopia & 2 \\
Vomiting & 1 \\
Symptoms of left ventricular failure & 13 \\
Nil & 143 \\
\hline
\end{tabular}

\section{Investigations}

Haemoglobin electrophoretic fractionation

Results of haemoglobin electrophoretic fractionation in 105 patients are as follows: AA 77, AS 19, SS 4 and AC 6. The frequency of the sickle cell gene in this series is 21 per cent.

\section{Urine examination}

Glycosuria was present in 39 patients, 7 of whom were subsequently found not to suffer from diabetes mellitus. Ketonuria without glycosurin was observed in 3 patients who were not diabetic. In 64 patients albumi-nuria was present. In 2 patients bacterium was confirmed by culture.

\section{Serum cholesterol}

Table XIII shows the level of serum cholesterol in NEICVD in Nigerians compared with serum levels in other groups. There is no difference in the levels of serum cholesterol in normal Nigerians from upper and middle socio-economic groups, patients with diabetic retinopathy and patients with NEICVD. The levels of serum cholesterol in Nigerians from poor socio-economic groups represented by normals from a village survey, and patients with diabetes mellitus without retinopathy are statistically significantly lower $(\mathrm{P}<0.05)$. 
Table IX. Non-enbolic ischaemic cerebrovascular disease in Nigerians, $1957-1968$

\begin{tabular}{|l|l|}
\hline Other physical findings & No. \\
\hline Dementia & 20 \\
Organic psychosis & 3 \\
Euphoria & 3 \\
Severe perseveration & 3 \\
Parietal lobe syndrome & 10 \\
Extra pyramidal disease & \\
Parkinsonism & 10 \\
Choreo-athetosis & 1 \\
Torsion dystonia & 1 \\
Pseudobulbar palsy & 2 \\
Cerebellar ataxia associated with & \\
i. Supratentorial lesion & 5 \\
ii. Brain stem lesion & 4 \\
Optic atrophy & 3 \\
Multiple & 3 \\
\hline
\end{tabular}

Table X. Non-embolic ischaemic cerebrovascular disease in Nigerian patien ts, UCH., Ibadan, 1957-1968. Dysphasia in 218 patients with completed strokes.

\begin{tabular}{|lc|l|l|}
\hline & $\begin{array}{c}\text { Total } \\
\text { No. }\end{array}$ & $\begin{array}{c}\text { No. with } \\
\text { Dysphasia }\end{array}$ & $\%$ \\
\hline Dextrals & & & 64.1 \\
Right hemiplegia & $128^{*}$ & 82 & 13.5 \\
Left Hemiparesis & 89 & 12 & \\
Sinistrals & & 1 & 100 \\
Left hemiparesis & 1 & 1 & \\
\hline
\end{tabular}

* In 24, clinical evidence of Subcortical infarct.

\section{Cerebrospinal fluid examination}

In 207 patients, the cerebrospinal fluid was examined and only twenty-four showed abnormalities with regard both to protein content and white cell count. In 7 of these, the protein content in $\mathrm{mg}$ per $100 \mathrm{ml}$. were $60,75,90,110,120,130$ and 1,000 , with corresponding white cell count per cmm. of 110 , 1,000, 90, 45, nil, and 950. Four of these 24 patients had positive serological test for syphilis in blood and CSF. Seventeen patients showed raised protein concentration only. This was usually moderate; only 4 had values exceeding $70 \mathrm{mg}$. per $100 \mathrm{ml}$. (85, 90, 150 and $500 \mathrm{mg} / 100 \mathrm{ml}$.). In 22 other patients with CSF the red blood cell count exceeded 550/c.mm. in 13; the protein content, white cell count, and sugar concentration were normal.

Table XI. Non-embolic ischaemic cerebrovascular disease in Nigerian patients, U.C.H., Ibadan, 1957-1968. Pure Motor Hemiplegia

\begin{tabular}{|l|c|l|l|}
\hline & No. & $\begin{array}{l}\text { Pure } \\
\text { motor } \\
\text { hemiplegia }\end{array}$ & $\%$ \\
\hline Hypertensive patients & 145 & 75 & 51.7 \\
Non-hypertensive & 79 & 21 & 26.6 \\
\hline
\end{tabular}

Table XII. Babinsli reflexin nonembolic isdhemic cerdbrovasalar diseasein Ngerians

\begin{tabular}{|l|cc|l|ll|}
\hline & No $\begin{array}{c}\text { Pesert } \\
\text { (+ve) }\end{array}$ & Hexor & Equivocal & $\begin{array}{l}\% \\
\text { tve }\end{array}$ \\
\hline $\begin{array}{l}\text { Right } \\
\text { hemiparesis }\end{array}$ & 128 & 42 & 54 & 32 & 328 \\
$\begin{array}{l}\text { Left } \\
\text { hemiparesis }\end{array}$ & 90 & 37 & 40 & 13 & 41.1 \\
Quadi-paresis & 12 & 6 & 4 & 2 & 50.0 \\
\hline
\end{tabular}

\section{Electrocardiographic abnormalities}

Transient ECG abnormalities were found in 12 patients - usually as flattening or depression of ST segment and $\mathrm{T}$ waves in left ventricular leads reverting to normal in most cases within one to two weeks. Left ventricular hypertrophy usually with evidence of myocardial strain was found in 39 patients. Other abnormalities include left atrial hypertrophy in one patient, left bundle branch block in 3 patients and diffuse myocardial damage in 4 patients who had severe hypertension and were in incipient cardiac failure.

\section{Contrast neuroradiological investigation}

Table XIV shows the abnormalities found. Preangiographic prediction of the site was correct in only 60 per cent. Representative findings are shown in Figs. 1-6.

Fig. 1. Shows complete occlusion of left Internal Carotid artery in the characteristic site just beyond the bifurcation of the common carotid, in a normotensive, non-diabetic man aged 45 , with transient ischaemic attacks. 
Table XIII. Serum cholesterol in non-embolic ischaemic Nigerians

\begin{tabular}{|l|r|l|}
\hline & No. & $\begin{array}{l}\text { Mean senum } \\
\text { cholesterol } \\
\text { inmg/100 ml. } \\
\text { (including S.D.) }\end{array}$ \\
\hline $\begin{array}{l}\text { 1. Non-embolic cerebro-vascular disease. } \\
\text { a. Total }\end{array}$ & 103 & $196 \pm 85$ \\
b. Male & 67 & $191 \pm 72$ \\
c. Female & 36 & $213 \pm 88$ \\
d. Transient ischaemic attacks & 23 & $208 \pm 570$ \\
& 285 & 200 \\
2. Edozien's reference group (1965) & 31 & $120 \pm 40$ \\
3. Normals fromvillage surveys (Epe- & 528 & $141 \pm 54$ \\
Ejinnin) & 32 & $190 \pm 60$ \\
4. Diabetes mellitus without & \\
5. Diabetes mellitus withretinopathy &
\end{tabular}

Table XIV. Non-embolic ischaemic cerebrovascular disease in Nigerians, University CollegeHospital, Ibadan, 1957-1968.

\begin{tabular}{|lr|r|}
\hline Contrast neuroradiological investigation & No. \\
\hline Internal carotid angiography & 74 \\
Arch Aortography & 3 \\
Pneumoencephalography \& angiography & 10 \\
Abnormal findings & 42 \\
Narrowed or occluded internal carotid & 11 & \\
Internal carotid siphon to basilar artery & 2 & \\
Stenosed external carotid in association & \\
with middle cerebral artery occlusion & 1 & \\
Occlusion of middle cerebral artery & 16 & \\
Occlusion of anterior cerebral artery & 2 & \\
Both anterior cerebral arteries fill from & \\
One side & 3 \\
Abnormal arch aortogram & \\
Pneumoencephalogram-unilateral dilation & \\
of ventricle (normal angiograms) & 4 & \\
Normal internal carotid angiography & 49 \\
\hline
\end{tabular}

Fig. 2. Shows stenosis of left external carotid near its origin and complete occlusion of middle cerebral artery in a 55 year old normotensive man, with a right hemiplegia and aphasia.

Fig. 3. Shows complete occlusion of the middle cerebral artery in a 50 year old hypertensive and diabetic woman.

Table XV shows that extracranial occlusion of stenosis was commoner in non-hypertensive patients although the difference is not statistically significant. Demonstrable angiographic occlusion of intracranial cerebral vessels was commoner in non-hypertensive patients than in hypertensive patients. The difference is statistically significant. $(\mathrm{P}>0.02)$.
Table XV. Arteriography in non-embolic cerebral infarcation in Nigerians

\begin{tabular}{|l|c|c|}
\hline \multirow{2}{*}{ Normal } & Normotensive & Hypertensive \\
\cline { 2 - 3 } & 21 & 28 \\
\hline Extracranial vessels & & \\
Occlusion & 4 & 4 \\
Stenosis & 3 & 4 \\
Intracranial & & \\
Arterial & & 3 \\
Occlusion & 13 & 36 \\
\hline Total & 41 & \\
\hline
\end{tabular}

\section{Mortality}

Thirty seven patients died giving a mortality rate of 15.7 per cent. Autopsy was done in 25 patients. The findings are shown in Table XVI. The patients with infarcts and no atheroma are under 40 .

Table XVI. Non-embolic ischaemic cerebrovascular disease.

\begin{tabular}{|l|c|}
\hline Post-mortem findings in 25 patients & \\
\hline Infarcts/atheroma of cerebral ve ssels, & $17^{*}$ \\
aorta, etc. & 4 \\
Middle cerebral artery occlusion & 1 \\
Snternal carotid artery occlusion & 1 \\
Infarct/no atheroma & 2 \\
Others: & 1 \\
Schistomiasis of bladder & 1 \\
\hline
\end{tabular}

* Occlusion of anterior descending branch of left coronary artery in a 61 year old male diabetic: no symptom of life.

\section{Sequelae to thrombotic infarcation}

Nine patients developed epilepsy after an interval of 3 months to 3 years (with a mean of eight months) after cerebral infarcation. In 4 patients, the thalamic syndrome of Dejerine - Roussy occurred; and one of them responded dramatically to anticonvulsant therapy using diphenylhydantoin (Epanutin). Twenty three patients were severely incapacitated. One patient a minister of state aged 53 developed myocardial infarcation presumably from concomitant coronary artery disease, 4 months after a stroke. Another patient, aged 68 , a wealthy businessman subsequently suffered from angina pectoris and intermittent claudication.

Fig. 4. Shows occlusion of some branches of the middle cerebral artery in a 45 year old man who presents with right hemiplegia and aphasia.

Fig. 5. Arch aortography in a 58 year old patient with severe hypertension: blood pressure on admission was $180 / 140 \mathrm{~mm}$. of $\mathrm{Hg}$. Shown arrowed is an aneurismal 
dilatation of the right innominate artery. The patient presented with T.I.A.s.

\section{Cerebral infarcation in non-diabetic non-bypertensive patients with no predisposing factors.}

We have encountered a group of relatively young normotensive non-diabetic patients with cerebral infarcation (Table XVIII). Hypercholestrolaemia was absent; angiographic studies demonstrated occlusion or stenosis in less than half of the patients.

Table XVII. sequelae to non-embolic ishcaemic cerebrovascular disease.

\begin{tabular}{|l|l|}
\hline & No. \\
\hline Epilepsy & 8 \\
Parkinsonism & 1 \\
Thalamic syndrome & 4 \\
Cardiac infarct & 1 \\
Angina pectoris & 1 \\
\hline
\end{tabular}

Fig. 6. Arch aortography in a 44 year old severely hypertensive (blood pressure 200/150 mm. Hg.) man, who presents with T.I.A.s. in the territory of the vertbrobasilar artery. Note irregularity of lumina of vertebral arteries.

\section{Sex and age distribution}

The male to female ratio in primary cerebral haemorrhage is 1.7 to 1 . The peak incidence is in the age group 40-59 (Table XIX). Patients from upper and middle socio-economic groups constitute 30 per cent of the total number (Table IV).

\section{Predisposing conditions}

Table XX shows that hypertension is present in 75 (81.5 per cent) of the patients. In 65 per cent of the patients hypertension has not been diagnosed prior to the ictus. The severity of the diastolic hypertension is shown in Table XXI. Cerebral haemorrhage occurred in association with leukaemia and Hodgkin's disease in 4 patients: thrombocytopenia was present. In two young female patients, cerebral haemorrhage was associated with chorioncarcinoma. Both patients gave a history of vaginal bleeding, recent abortion and were severely anaemic.

\section{Prodromal symptoms}

A history of vascular headache, the duration of which varied from hours to weeks, prior to the ictus was obtained in 28 patients (30 per cent). Seven other patients had symptoms of left ventricular failure 1 to 4 weeks before the stroke. Other symptoms were confusion (1) dizziness (1) hemi-hyperaesthesia (1) vomiting, associated with ataxia and diplopia (1), and convulsion (1)
Table XVIII. Non-embolic ischaemic cerebrovascular disease

\begin{tabular}{|ll|}
\hline \multicolumn{2}{|c|}{ No predisposing condition } \\
\hline No. of patients & 41 \\
M:F ratio & $5.8: 1$ \\
Middle \& Upper socio- & $31.7 \%$ \\
economic classes & \\
Age (mean range and S.D.) & $46.5(13-7) \pm 16$ \\
in years & \\
$\begin{array}{l}\text { Serumcholesterol (mean, } \\
\text { and S.D.) }\end{array}$ & $149.0 \mathrm{mg} / 100 \mathrm{ml} \pm 43$ \\
Mortality & $19.5 \%$ \\
Contrast neuroradiological & \\
investigations & 26 \\
Normal & 15 \\
Abnormal & 11 \\
\hline
\end{tabular}

\section{Mode of onset}

It was sudden in 89 patients and was precipitated by excitement in a few patients. One man aged 35 years, on being told his wife had just delivered their first baby boy, after four girls, jumped up in ecstasy and collapsed. On admission, he was in coma and had right hemiplegia: his blood pressure was 260/180, and he died within 24 hours of admission. One patient developed a CVA whilst watching a football match: in another patient CVA occurred during a religious ecstasy in the Church of Cherubim and Seraphim. Only in one patient did the stroke occur during sleep. In 2 other patients, the onset was gradual taking 30 minutes and 2 hours respectively for the hemiplegia to be completed.

\section{Physical signs on admission}

Table XXII shows that coma or semi coma was present in 71 (77 per cent) of the patients. On clinical grounds, the haemorrhage was supratentorial in 79 patients and was in the brain stem in 13 patients.

\section{Investigations \\ Haematology}

Of the 5 patients in whom the haemoglobin level was less than $5 . \mathrm{G} / 100 \mathrm{ml}$, chorioncarcinoma was present in 2 and leukaemia in 3. Haemoglobin electrophoretic fractionation in 25 patients gave the following results: AA 18, AS 5, AC 2, giving a frequency of 20 per cent for the sickle cell gene in patients with primary intracerebral haemorrhage.

\section{Cerebrospinal fluid examination}

Cerebrospinal fluid examination was done in 54 patients. In 31, it was uniformly bloody, in 18 it was xanthocromic. In 5 patients it was clear microscopically but red blood cells count exceeded 1,000/c.mm. Three of the patients subsequently died and autopsy showed intracerebral haemorrhage. 
Table XIX. A ge distribution in 92 patients with primary intracerebral haemorrhage

\begin{tabular}{|l|c|c|c|c|c|c|c|c|}
\hline A ge groups & $10-19$ & $20-29$ & $30-39$ & $40-49$ & $50-59$ & $60-69$ & $70-79$ & To tal \\
\hline $\mathrm{M}$ & 3 & 4 & 9 & 13 & 14 & 9 & 6 & 58 \\
\hline $\mathrm{M}$ & 2 & 2 & 5 & 9 & 8 & 8 & - & 34 \\
\hline Total & 5 & 6 & 14 & 22 & 22 & 17 & 6 & - \\
\hline
\end{tabular}

Table XX. Cerebral haemorrhage in Nigerians

\begin{tabular}{|l|l|}
\hline \multicolumn{1}{|c|}{ Predisposing conditions } & No. \\
Hypertension & 75 \\
Diabetes mellitus and hypertension & 8 \\
Leukaemia & 3 \\
Trophoblastic tumours & 2 \\
Hodgkin's diseases & 1 \\
Nil & 3 \\
& \\
\hline & Total \\
\hline
\end{tabular}

Table XXI. Cerebral haemorrhage in Nigerians

\begin{tabular}{|l|l|}
\hline $\begin{array}{l}\text { Severity of diastolic } \\
\text { hyperten sion }\end{array}$ & No. \\
\hline$>120 \mathrm{~mm} . \mathrm{Hg}$. & 52 \\
$>130 \mathrm{~mm} . \mathrm{Hg}$. & 37 \\
$>140 \mathrm{~mm} . \mathrm{Hg}$. & 27 \\
$>150 \mathrm{~mm} . \mathrm{Hg}$. & 16 \\
$>160 \mathrm{~mm} . \mathrm{Hg}$. & 13 \\
$>170 \mathrm{~mm} . \mathrm{Hg}$. & 8 \\
$>180 \mathrm{~mm} . \mathrm{Hg}$. & 6 \\
\hline
\end{tabular}

Urine examination

Albuminuria was present in 35 of the 63 patients in whom the urine was examined. Transient ketonuria without glycosuria was present in 3 patients.

\section{Serum cholesterol}

The mean in 20 patients was $202 \pm 40 \mathrm{mg} / 100 \mathrm{ml}$.

\section{Electrocardiography}

EGG evidence of severe left ventricular hypertrophy or strain was present in 48 hypertensive patients.

\section{Carotid angiography}

Angiography study was done in 6 patients. In one patient it showed an avascular frontal lobe mass which at craniotomy turned out to be an intracerebral haematoma. Angiography was not frequently done as the majority of the patients were in coma on admission.

\section{Mortality}

Seventy one (77 per cent) of the patients died. Twothirds of deaths occurred within 24 hours of admission, and 85 per cent of deaths within 3 days of admission. Permission for autopsy examination was obtained for 41 patients. The findings are shown in Table XXIII. In 25 patients intracerebral haemorrhage and macroscopically recognizable atheroma of the cerebral vessels were present. Fourteen patients under 40 years of age showed intracerebral haemorrhage but without any macroscopic atheroma of cerebral vessels. In one patient the arteries of cerebral vessels, pancreas, spleen, and kidneys showed histological changes typical of polyartentis nodosa (Fig. 7). This is the nearest to the establishment of a diagnosis of polyarteritis in U.C.H., Ibadan, in eleven years.

Table XXII. Cerebral haemorrhage

in Nigerians

\begin{tabular}{|l|c|}
\hline & No. of patients \\
\hline Coma & 68 \\
Semicoma & 3 \\
Confusion & 5 \\
Neck stiffness & 13 \\
Dementia & 3 \\
\hline
\end{tabular}

Table XXIII. Cerebral haemorrhage in Nigerians

\begin{tabular}{|l|c|}
\hline Severity of diastolic hypertension & No. \\
\hline Haemorrhage/ath eroma & 25 \\
Haemorrhage/ no atheroma & 14 \\
Chorion carcinoma/haemorrhage & 1 \\
Leukaemia/haemorrhage & 1 \\
\hline
\end{tabular}

Sequelae to cerebral haemorrhage

Eight patients were severely incapacitated. One patient developed epilepsy 6 months after the ictus.

Fig. 7. (Magnification x 150). Shows occlusive arteritis in the pancreas in an 18 year old patient who presents as cerebral haemorrhage and died. ?Polyarteritis nodosa

\section{Embolic infarcation}

Sex and age distribution

The male to female ratio is 1.6 to 1 . The youngest patient was 3 years old and the oldest 75 . Only one of 
the 21 patients came from the upper and middle socioeconomic groups.

\section{Predisposing conditions}

In 12 patients, embolic infarcation was secondary, to rheumatic mitral valve disease; in 3 of the patients, arterial fibrillation was present. Subacute bacterial endocarditis was present in 6 other patients with vulvar disease who subsequently developed embolic infarcations, in association with evidence of embolic infarcation in the kidneys. In 2 patients with endomyocardial fibrosis and in another patient with heart muscle disease, embolic cerebral infarcation occurred as a complication.

\section{Clinical features}

Onset was sudden in all the patients. At the onset of ictus, only three patients were in coma and one was confused. Left hemiparesis was present in 13 patients who were all right-handed; and eight other righthanded patients had right hemiparesis. Hemianopia was present in 2 patients. Aphasia was present in 7 of the 8 right-handed patients with right hemiparesis. None of the patients with left hemiparesis showed any disorder of speech.

\section{Cerebrospinal fluid examination}

In 14 patients the CSF was examined and was normal in all except 2 patients whose CSF showed protein conventrations of $70 \mathrm{mg}$. and $110 \mathrm{mg}$. per $100 \mathrm{ml}$ : there was no increase in the cellular content of the CSF.

\section{Mortality}

Nine (including the 6 patients with bacterial endocarditis) of the 21 patients died, giving a mortality rate of 42.9 per cent.

\section{Sequelae}

Two patients developed epilepsy 4 and 6 months after embolic cerebral infarcation. One of them died 2 years after the onset of epilepsy, from cow's urine poisoning administered as a native anticonvulsant. Eight patients achieved satisfactory functional recovery. Two patients were severely incapacitated largely as a result of cardiac valvular lesion.

\section{Discussion}

Non-embolic ischaemic cerebrovascular disease is the commonest form of CVA in Nigerians. Our finding is similar to that of the National Institute of Neurological Diseases and Blindness U.S.A. (1958), Prineas and Marshall, (1966), Yates (1964), Collomb et al. (1966) and DaLAL et al. (1968). In the more developed countries there is evidence that 3 or 4 decades ago, cerebral haemorrhage caused death in three times the number of cases as did cerebral infarcation. The reversal in recent times has been attributed to various possibilities including the use of hypotensive therapy (LEISHMAN 1963), which reduces the mortality from an early stroke due to cerebral haemorrhage but has little influence upon the longterm risk of dying from a stroke associated with the progressive development of cerebral atherosclerosis. It is interesting to note that in Nigerians this factor of early use of hypotensive therapy does not apply; for hypertension was previously undiagnosed before the occurrence of CVA, in 60 per cent of our patients with either NEICVD or cerebral haemorrhage, and who were subsequently found to be hypertensive. Hence although a clinical diagnosis of cerebral arterial thrombosis is more frequently made at Ibadan, cerebral haemorrhage, with or without atheroma of cerebral vessels, is more frequently found at autopsy. In this series for example, 41 patients with cerebral haemorrhage were found at autopsy compared with 25 non-embolic infarcations. Besides cerebral haemorrhage accounted fir nearly twice as many deaths as thrombotic cerebral infarcation, although the latter is more than twice as common.

The peak incidence of non-embolic cerebral infarcation as well as that of cerebral haemorrhage is in the age group 50-59; and this is a decade ahead of the peak incidence of hypertension in Nigerians, (AKINKUGBE, 1968). In both groups, hypertension is the commonest predisposing factor.

The sex incidence for all types of CVA in Nigerian is similar. In most African countries, the males come more readily to the hospital, and hence the sex incidence in this series may not reflect the true sex incidence.

Non-embolic cerebral infarcation and cerebral haemorrhage are commoner among the middle and upper socio-economic groups compared for example with a disease such as epilepsy or with embolic cerebral infarcation. Most of the patients in the higher and middle socio-economic groups live in the big cities such as Ibadan. It has been established elsewhere that

Table XXIV. Embolic infarcations in Nigerians. Age and sex distribution

\begin{tabular}{|c|c|c|c|c|c|c|c|c|}
\hline \multirow{2}{*}{$\begin{array}{l}\text { Age group } \\
\text { in years }\end{array}$} & & & & & & & & \\
\hline & $0-9$ & $10-19$ & $20-29$ & $30-39$ & $40-49$ & $50-59$ & 60-69 & $70+$ \\
\hline Male & 1 & 3 & 0 & 4 & 2 & 1 & 1 & 1 \\
\hline Female & 0 & 1 & 3 & 2 & 1 & 1 & 0 & 0 \\
\hline Total & 1 & 4 & 3 & 6 & 3 & 2 & 1 & 1 \\
\hline
\end{tabular}


mortality from vascular disease is greater in urban than in rural areas. For example, BERKSON et al. (1960) have shown that mortality from cardiovascular and renal disease is twice as high in Chicago as it is in rural Illinois and similar findings have been reported for coronary artery disease and for CVD by JERVELL et al. (1965).

Hypertension and diabetes mellitus constitute the most important predisposing conditions for non-embolic cerebral infarcation and cerebral haemorrhage in Nigerians. Prospective studies of small towns in Britain and United States of America (HALL, 1965, MiKKELSON et al., 1965) have shown that hypertension, diabetes, obesity, high serum lipids and smoking predispose. COLE and McDowell, (1968) concludes from their epidemiological studies of CVD that hypertension has emerged as the single factor most closely associated with the later development of a stroke although a striking preponderance of diabetes mellitus and hypercholestrolaemia is also evident among those who later develop a stroke. Hypertension is more readily accepted as being of aetiological importance in cerebral haemorrhage; however there is also an abundance of data showing that hypertension is common in cerebral infarcation (HutChinson and Yates, 1957, StAMLER, 1958, Lowbeer and PheAr, 1961). In our series however, hypertension is more common in cerebral haemorrhage than in cerebral infarcation.

It is worth emphasizing the role of diabetes mellitus in the pathogenesis of CVD in Nigerians, and that there may be no overt symptom of diabetes mellitus. In 16 of our patients with non-embolic ischaemic disease and who on admission were known not to suffer from overt diabetes mellitus, impaired glucose tolerance was found with the standard and the sterbidstressed GT'T. Diabetes mellitus is not uncommon in Nigerian; the incidence in the hospital population in U.C.H., Ibadan is 0.43 per cent. (OSUNTOKUN et al., 1969b). The role of diabetes mellitus or of diabetic diathesis in the aetio-pathogenesis of CVD has been discussed in detail elsewhere. (OSUNTOKUN et al., 1969a). Haemoglobinopathy is not a predisposing factor to CVA in adult Nigerians but should be borne in mind in children who presents with a CVA. Sickle cell disease may be a cause of monocular blindness in the African (KONOTEY-AHULU, 1968) and this may stimulate transient ischaemic CVD. The frequency of the sickle cell gene in NEICVD and in cerebral haemorrhage is 21 and 20 per cent respectively and is not higher than in the general population where the frequency is 24 per cent (WATSON-WILLIAMS, 1965).

Transient ischameic attacks (TIAs) appear to carry a bad prognosis in Nigerian patients, compared with the Caucasians. In MARSHALL's (1964) series of 61 patients with TIAs followed for a period of two months to 7 years, only one patient subsequently developed a major episode. In our series, of the 15 oatients who suffered from intermittent ischaemia of the internal carotid territory, and who were followed up 6 months to 10 years, 11 developed major strokes and one of them died. One of the 8 patients with intermittent vertebrobasilar ischaemia had a completed stroke and died from it - this group has been followed up for 6 months to 4 years. However, our finding in one respect is similar to that of MARSHALL (1964) who found that TIAs in the vertrbrobasilar territory carry a better prognosis than those in the internal carotid territory with regard to completed stroke.

The clinical features of non-embolic infarction, cerebral haemorrhage and embolic infarction were frequently characteristic to make accurate clinical diagnosis possible in a large number of patients. As has been noted by several authors, this is not always possible however without ancillary investigations. For example although non-embolic infarction was gradual in onset, or followed sleep, in 192 patients; however in 27 patients it was sudden, and angiography or autopsy examination was necessary to establish the diagnosis of non-embolic infarction in these 27 patients. In 2 patients with cerebral haemorrhage, the onset was gradual. Coma was frequently present in cerebral haemorrhage, less so in embolic infarctions and least common in cerebral haemorrhage (30 per cent) and less common in non-embolic and embolic infarctions (15 and 14 per cent respectively). The CSF was frequently bloody or xanthochromic in cerebral haemorrhage and rarely so in embolic and thrombotic infarction. The mortality was highest in cerebral haemorrhage. Epilepsy as a sequel was more frequent in thrombotic and embolic infarctions than in cerebral haemorrhage. There is a group of relatively young normotensive non-diabetic Nigerian patients with nonembolic cerebral infarction in whom hypercholesterolaemia is usually absent and angiographic examination reveals stenosis or occlusion in less than half of the patients. This group deserves further intensive study including measurement of fibrinolytic activity, platelet adhesiveness, parasitisation rate, and arterial biopsy for evidence of arteritis. It is interesting to note that a similar group has been described among Indians in Bombay (DALAL et al.,) ABRAHAMS and COCKSHOT (1962) reported a peculiar arteritis which present with multiple aneurysms. We have not found such an entity as a cause of stroke in young Nigerians.

In Nigerians with NEICVD, the higher incidence of pure motor hemiplegia in hypertensive patients than in normotensive patients is similar to the findings of PRINEAS and MARSHALL (1966). Pure motor hemiplegia is usually due to thrombosis of small vessels causing a deeply situated lesion in the internal capsule or pars basilaris pontis (FISHER and CURRY, 1965). 
The high socio-economic status of many of our patients with non-embolic CVA and cerebral haemorrhage is also reflected in the serum cholesterol values. The values in the two groups are comparable to those found in healthy Nigerians from the upper socio-economic strata. Serum cholesterol appears to reflect the socioeconomic status in Nigerians. Serum cholesterol levels are higher in Nigerians in upper and middle socioeconomic groups than in the low-income groups. The serum cholesterol in patients with cerebral infarction is of the same level in Nigerians with diabetic retinopathy (OSUNTOKUN, 1969c). In both groups there is a preponderance of patients from the middle and upper socio-economic groups. Nigerians in the higher strata of the society eat partly European type of diet. Bantus who eat European type of diet with high fat intake have higher serum cholesterol than Bantus who live on native diet with low fat intake (WALKER and ARVIDSSON, 1954). The diet of an average Nigerian from the low-income group includes a large amount of unsaturated vegetable fats in addition to lots of carbohydrate, vegetables and pulses, but little protein derived from animal sources; in addition physical exertion is often excessive, as they way walk long distances daily: these may account for the low serum cholesterol in such patients. Serum cholesterol is low in the Bushmen of the Kalahari Desert, probably due to low calorie intake and excessive physical work (TRUSWELL and HANSEN, 1968). There is evidence that although there may be no significant difference in the level of serum cholesterol in patients with strokes and in normals, the phospholids and triglyceride levels may be significantly higher than normal in cerebral thrombosis (Technical Group of the Committee on Lipoprotein and Atherosclerosis, 1956; STAMBLER, 1960; KOGAN et al., 1962, BERKOWITZ, 1964, KATSUKI and OMAE, 1966). However, CUMINGS et al., (1967) found no difference in the serum triglycerides, total and free cholesterol, phospholipids, free fatty acids and skin fold thickness in patients with cerebral infarction whether hypertensive or not, and in controls. The role of serum lipids in the aetio-pathogenesis of cerebral atherosclerosis remains therefore controversial.

The incidence of extracranial obstructive arterial lesions in our patients with NEICVD is low at 19.6 per cent of the 87 patients in whom angiographic examination was carried out. The incidence is most series is 40 to 50 per cent (BAUER et al., 1962; BLAIDSDELL et al., 1962; NEWTON et al., 1964: DALAL et al., 1968). Four vessel angiography was infrequently employed in our patients and this may have accounted for the marked difference in the incidence of extracranial arterial obstructive lesion. DALAL et al. (1968) has shown that there is no significant difference in the frequency if these lesions in the malnourished and wellnourished subjects; that there is no correlation found with the level of serum cholesterol; and that in the low-income Indians from low-socio-economic groups the angiographic incidence of extracranial lesions associated with ischaemic stroke showed no significant difference from that seen in the Caucasians. There may however be subtle racial differences, for in a comparative study, KIEFFER et al. (1967) show that the incidence of extracranial lesions demonstrable by 4-vessel angiography in the American patients is higher than in the Japanese.

Angiographically verified extracranial and intracranial arterial stenosis or occlusion is more common in the non-hypertensive than in the hypertensive Nigerian patients with thrombotic cerebral infarction. This is similar to the finding of PRINEAS and MARSHALL (1966). Non-haemorrhage stroke in the hypertensive patient may be due to occlusion in small vessels which may not be demonstrable by angiography. ROSS RUSSELL (1963) has demonstrated a higher incidence of miliary aneurysms on the cerebral arteries of hypertensive patients than in normotensive subjects. These aneurysms were found most commonly upon the small perforating arteries. They showed a tendency of thrombose, a process which sometimes extend to affect the parent vessel with the production of small areas of ischaemic softening in the distribution of the vessels. There was often no evidence of present or past haemorrhage in the area of the aneurysm. Such occlusive disease may not be demonstrable by angiography.

Angiography showed evidence of atherosclerotic occlusion in less than half of the patients in our series in whom this examination was done. A negative angiography however does not rule out occlusive disease of the small perforating arteries at the base of the brain. The incidence of normal angiograms in occlusive cerebrovascular disease ranges from 19 per cent to 51 per cent (NEWTON et al., 1964; SILVERSTEIN, 1965, DALAL et al., 1968). In some patients immediate recanalisation from lysis of a thrombotic plug is a possibility but is unlikely. DALAL et al. (1968) has reported the finding of ischaemic infarctions with thrombotic occlusion of the smaller perforating arteries in patients who have normal multiple angiograms. We also encountered 2 such patients in our series. A negative or normal angiogram in the ictal territory in non-embolic infarction is suggestive of an occlusive disease in the blood vessels too small to be visualized by angiography. It should be borne in mind however that temporary or transient cerebral arterial spasm may cause infarction of the brain as has been reported in migraine (GUEST and WOOLF, 1964). Angiographic investigation is of value in the investigation of a stroke but it is not without risk in patients who are hypertensive and in elderly patients. Our criteria for deciding on angiographic examination have been set out elsewhere (OSUNTOKUN et al., 1969a). Judiciously employed angiography is a relatively safe procedure. In this series, 5.8 per cent of patients with NEICVD who had angiographic examination developed complications. The incidence of complications of angiographic examinations in occlusive vascular disease has ranged from 2.2 to 20 per cent per patient or 2 to 13 per cent procedure (SILVERSTEIN, 1966). 
This series show that cerebrovascular accident is not uncommon in the Nigerians. In U.C.H., Ibadan, the incidence of cerebrovascular accident is 60 per cent of that of epilepsy and 40 per cent of that of diabetes mellitus. It is more common than nutritional neuropathies, cerebral tumours, motor neurone disease, and Parkinson's disease. Its incidence in the hospital population is 1 in 560. In a previous study in the U.C.H., Ibadan, KAUSHIK (1963) found that cerebrovascular accidents constitute 16.3 per cent of all neurological admissions, 0.35 per cent of the total admissions, and 44 per cent of the patients who had CVA suffered from non-embolic infarction. At autopsy cerebrovascular atheroma and cerebral arterial occlusion are not infrequently encountered especially in patients with diabetes mellitus and hypertension. Cerebrovascular atheroma in the nom-diabetic nonhypertensive Nigerians is less common at autopsy compared with American Negroes (WILLIAMS and RESCH, 1969). However it is now being recognized that a high incidence of cerebrovascular disease may occur even when there is a low incidence of advanced atherosclerotic process in the cerebral vessels. This has been demonstrated in the Japanese population where it has been shown that cerebral thrombosis is quite common although cerebrovascular atherosclerosis is less common than in the white American (KATSUKI and HIROTA, 1966). Besides although atherosclerosis is less common in the South African Bantus, cerebrovascular disease is as common as in the whites. (WALKER, 1963).

The relatively rarity of embolic infarction in Nigerians is probably due to the low incidence of rheumatic heart disease and ischaemic heart disease. Endomyocardial fibrosis and heart muscle disease are the commonest heart diseases seen at Ibadan. In these diseases the incidence of embolic infarction seems to be low.

\section{Summary}

In the 11 year period, 1957 to 1968,348 patients with cerebrovascular accidents (thrombosis, haemorrhage and embolism) have been seen in the University College Hospital, Ibadan. In the same period, at least 200,000 patients have been treated in the various departments and wards of the hospital.

Non-embolic ischaemic cerebrovascular disease constitutes 67.5 per cent of all CVA, cerebral haemorrhage 26.4 per cent and embolic infarction 6.1 per cent.

There is a male preponderance in all the three categories. The peak incidence of non-embolic ischaemic disease and cerebral haemorrhage is in the age group 50-59. The most important predisposing factors to nonembolic infarction and cerebral haemorrhage are hypertension and diabetes mellitus. The former is commoner in non-embolic cerebral haemorrhage; diabetes mellitus is commoner in non-embolic cerebral infarction than in cerebral haemorrhage. Rheumatic heart disease and subacute bacterial endocarditis are the major predisposing conditions to embolic infarction.

TRUSWELL, A. S. \& HANSEN, J. D. L. (1968). Lancet, 2, 684.
A third of the patients with non-embolic infarction and cerebral haemorrhage come from the upper and middle socio-economic groups.

The prognosis in transient ischaemic attacks in Nigerians is worse than in Caucasians. The prognosis with regards to completed strokes is better in intermittent ischaemia of the vertebrobasilar territory than in intermittent ischaemia of the internal carotid territory.

Haemoglobinopathy is not a factor in the aetiopathogenesis of stroke in the adult, but may be in children.

Serum cholesterol levels in Nigerian patients with cerebral haemorrhage and non-embolic infarction merely reflects the high socio-economic groups of these patients; the levels are not different from that of normal Nigerians in the same socio-economic groups. Angiographic examination showed abnormalities in about 50 per cent of patients with non-embolic infarction.
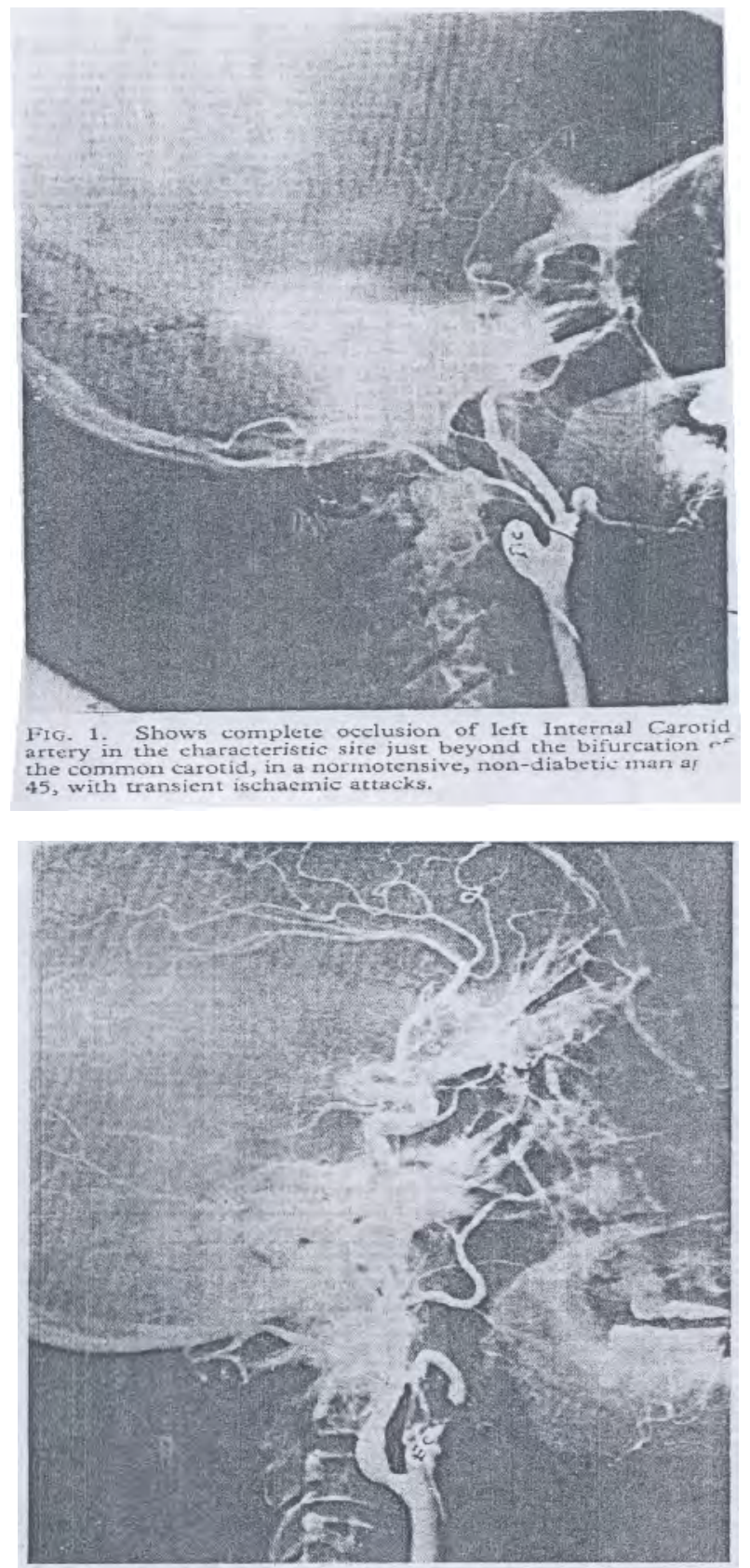

Fig. 2. Shows stenosis of left external carotid near its origin ind complete occlusion of middle cerebral artery in a 55 year
9 normotensive man, with a right hemiplegia and aphasia. 


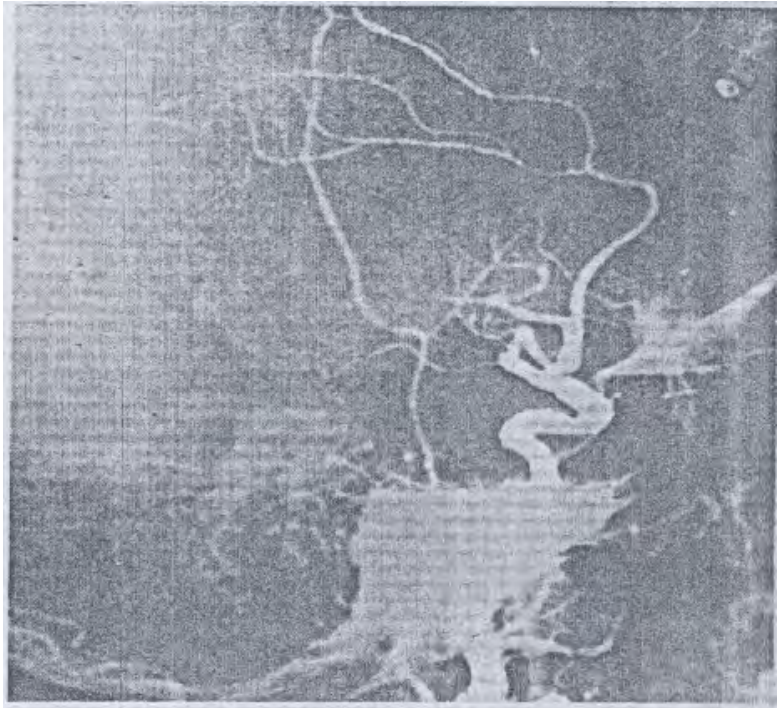

FIG, 3, Shows complete occlusion of the middle cerehral artery in a 50 year old hypertensive and diabetic woman.

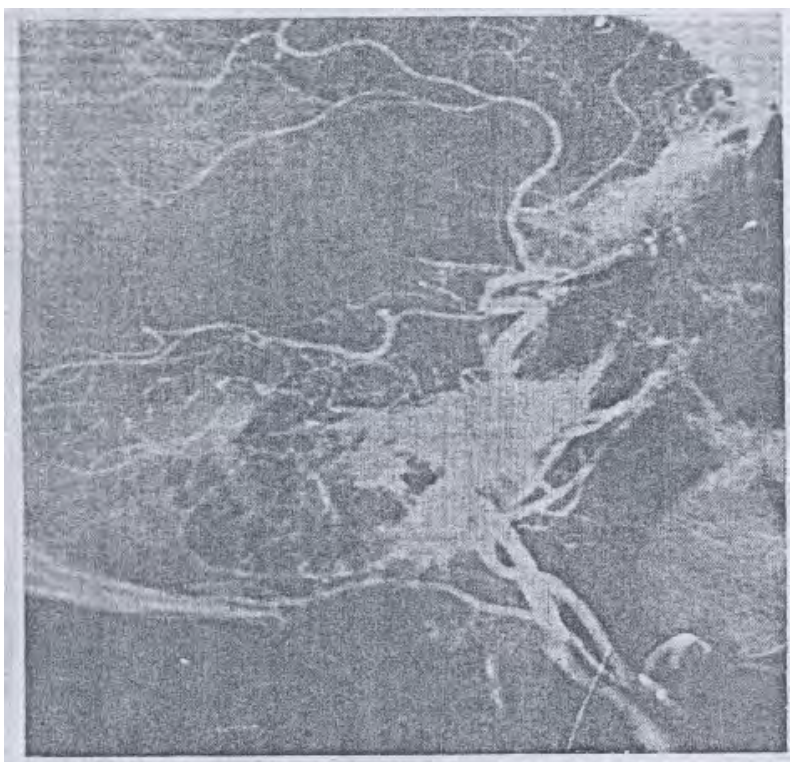

FIG. 4. Shows occlusion of some branches of the middl cerebral arrery in 45 year old man who presents with right hemiplegia and aphasia.

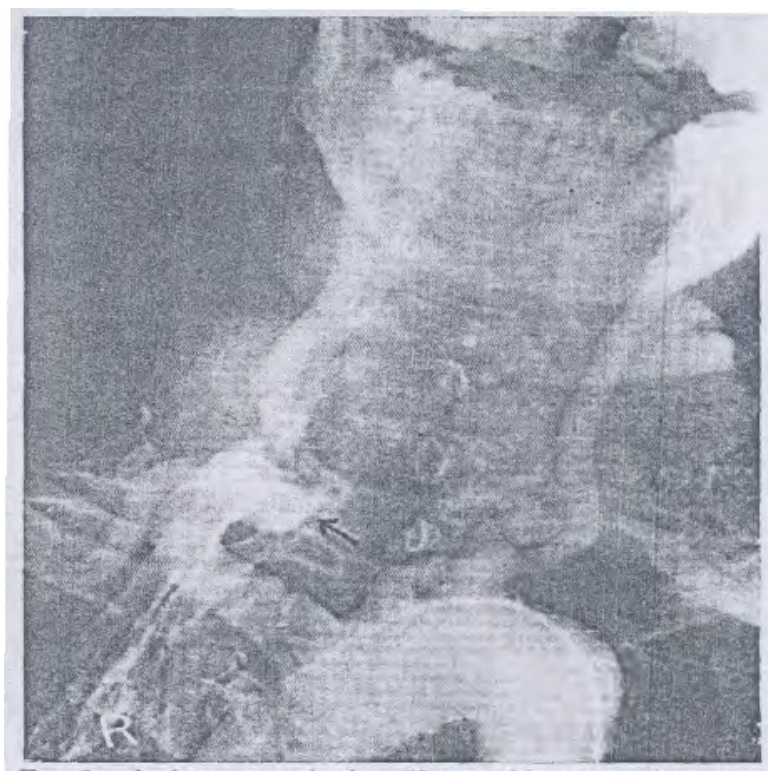

F1G. 5. Arch aortography in a 58 year old patient with severe hypertension: blood pressure on admission was $180 / 140 \mathrm{~mm}$.

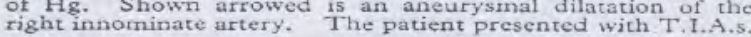
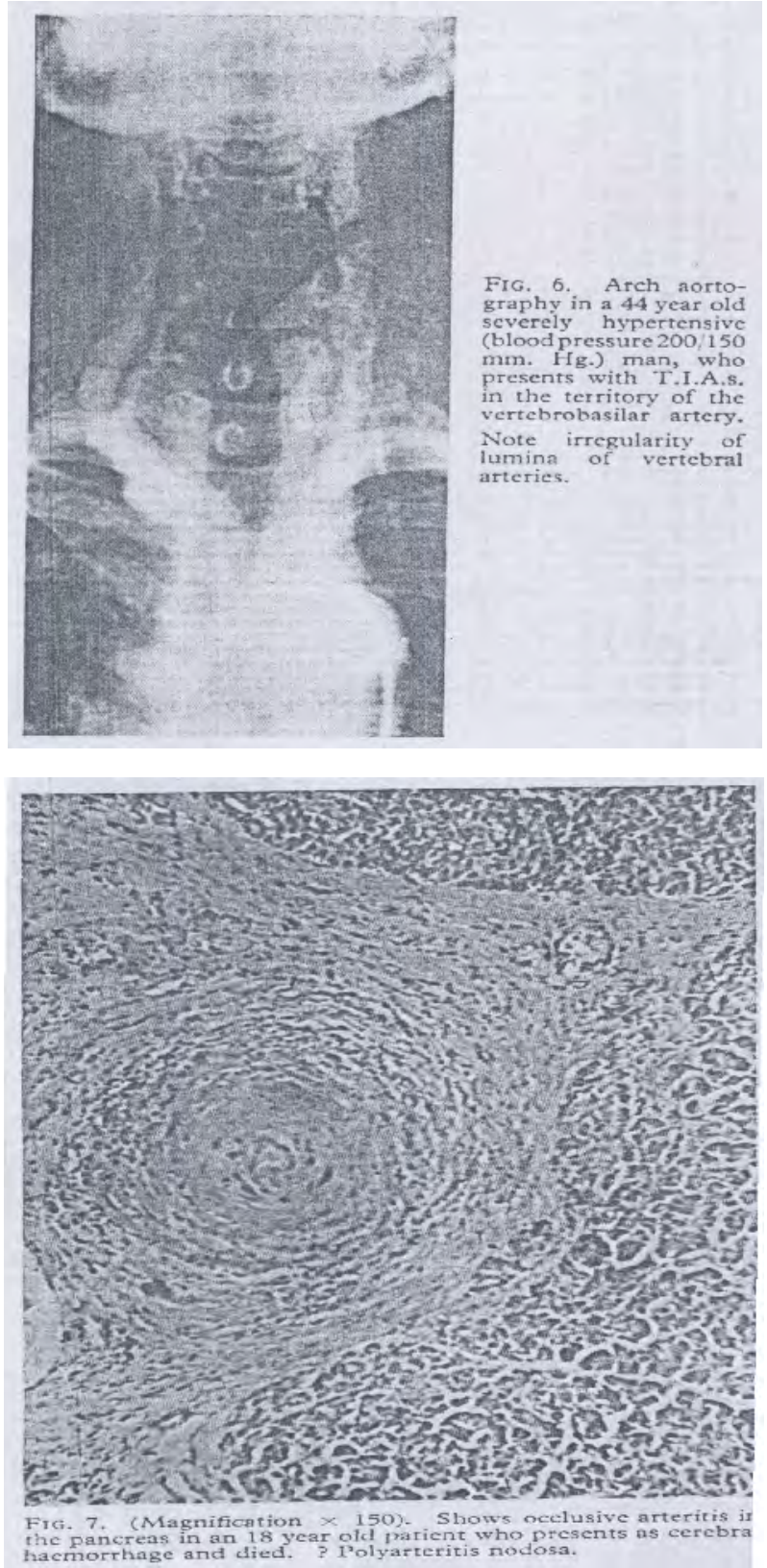

The mortality of cerebral haemorrhage is highest. Cerebral haemorrhage is more commonly seen at autopsy than cerebral infarction. Epilepsy is a more frequent seqeulae of cerebral infarction whether nonembolic or embolic than of cerebral haemorrhage. A brief description of the clinical features of the presentation of CVAs in Nigerians is given, and the various findings are discussed. Cerebrovascular accident is not uncommon in Nigerians.

\section{References}

ABRAHAMS, D. G. \& COCKSHOTT, W. P. (1962). Brit. Heart J. 24,83

AKINKUGBE, O. O. (1968) Personal communication

ARING, C. D. \& MERRIT, H. H. (1935) .Arch. intern. Med., 56, 435

BAUER, R. B., SHEEHAN, S., WECHSLER, N. \& MEYER, J. S (1962). Neurology (Minneap.), 12,k 698. 
BERKOWITZ, D. (1964). J.A.M.A., 190, 856.

BERKSON, D. M., STAMLER, J., LINDBERG, H. A., MILLER, W., MATHIES, H., LASKY, H. \& HALL, Y. (1960), Ann. N. Y. Acad. Sci., 84, 835.

BLAISDELL, F. W., GAUDER, P. J. \& HALL, A. D. (1962), Arch. Surg. (Chicago), 85, 41.

BRADSHAW, P. \& McQUAID, P. (1963), Quart. J. Med., 32, 279

BULL, J. W. D. (1958). Brit. Med. J., i, 792.

MARSHALL, J. \& SHAW, D. A. (1960). Lancet, 1, 562.

COLE, M., \& McDOWELL, F. (1968). Quited by Lancet: leading article, 1, 238.

COLlOMB, H., DUMAS, M. \& LEMERCIER, G., (1966). Bull. Soc. Med., Afr. Noire Lang. Franc, XI, 54.

CUMINGS, J. N., GRUNDT, I. K., HOLLAND, J. T. \& MARSHALL, J. (1967). Lancet, 2, 194.

DAAlsgaARD-NIElSEN, T. (1956). Acta. Psychiat. Scand. Suppl., 108, 101.

DALAL, P. M., SHAM, P. M., AIYAR, R. R., \& KIKANI, B. J (1968), Brit. Med. J., 3, 769.

EDOZIEN, J. C. (1965). J. West Afr. Sci. Assoc., 10, 3. , (1966) Personal communication

FISHER, C. M. \& CURRY, H. B. (1965). Arch. Neurol (Chicago), 13, 30 .

GUEST, I. A. \& WOOLF, A. L. (1964). Brit. Med. J., 1, 225.

HALL, A. P. (1965). Arthritis Rheum., 8. 846

HEASMAN, M. A., \& LIPWORTH, L. (1966). Accuracy of certification of causes of death. London, HMSO.

HUMPHRIES, S. V. (1957). S. Afr. Med. J., 31, 694. HUTCHINSON, E. C. \& YATES, P. O. (1957). Lancet, 1, 2.

JACKSON, W. P. U. (1961). Diabetes, 10, 33.

JERVELL, A., MEYER, K. \& WESTLUND, K. (1965), Acta Med. Scand., 177, 13.

KAGAN, A., DAWBER, T. R., KANNEL, W. B. \& REVOTSKIE, N. (1962). Fed. Proc., 21, 52

KATSUKI, S. \& OMAE, T. (1966). Thule International Symposia. Stroke Symposium, p. 215. Nordiska Bohkaudelns Forlag, Stockholm.

KATUSKI, S. \& HIROTA, Y. (1966) in Cerebrovascular diseases. New York, Grune and Stratton, Inc. 1966.
KAUSHIK, S. C. (1963) in First Pan-African Psychiatric Conference pp.78-80. Western Nigerian, Govt. Printer, Ibadan.

KIEFFER, S. A., TAKEYA, Y., RESCH, J. A. \& AMPLATZ, K. (1967) Amer. J. Roentgen., 101, 94.

KONOTEY-AHULU, F. I. D. (1968). Lancet, 2, 222.

LAURIE, W. \& WOODS, J. D. (1958). Lancet, 1, 231

LEISHMAN, A. W. D. (1963). Lancet, 1, 1284.

LINDNER, D. W., HARDY, W. G., THOMAS, L. M. \& GURDJIAN, E. S. (1962). J. Neurosurg. 19, 179.

LOW-BEER, T. \& PHEAR, D. (1961). Lancet, 1, 1303.

MARSHALL, J. (1964). Quart. J. Med., 33, 309. (1967). Scot. Med. J. 12, 335.

MIKKELSON, W. M., DODGE, H. J., \& VALKENBURG, H. (1965). Amer. J. Med., 39, 242.

NATIONAL INSTITUTE OF NEUROLOGICAL DISEASES AND BLINDNESS, PUBLIC HEALTH SERVICE, U.S.A. (1958). Neurology (Minneap.), 8, 1.

NEWTON, T. H., ADAMS, J. E. \& WYLIE, E. J. (1964). New Engl. J. Med., 270, 14.

OSUNTOKUN, B. O., ODEKU, E. L. \& ADELOYE, R. B. A. (1969a). Non-embolic cerebrovascular disease in Nigerians. J. Neurol. Sci. 9, October, 1969.

OSUNTOKUN, B. O., FRANCIS, T. I., AKINKUGBE F. M., LADIPO, G. O. \& BEWAJI, O. (1969b). Diabetes Mellitus in Nigerians. In prep.

, (1969c). Some observations in diabetic retinopathy in Nigerians. Brit. J. Ophthal., November, 1969.

PRINEAS, J. \& MARSHALL, J. (1966). Brit. Med. J., 1, 14.

RUSSEL, R. W. \& ROSS (1963). Brain, 86, 425.

SEARCY, R. L. \& BERCQUIST, L. M. (1960). Clin. Chim. Acta., 5, 192.

SILVERSTEIN, A. (1965). Arch. Neurol. (Chicago), 13, 441. (1966). Arch. Neurol. (Chicago), 15, 206

STAMLER, J. (1958) in Cerebral vascular disease. Ed. by C. H. Millikan, New York.

STAMLER, J. (1960). Prog. Cardiov. (Chicago) Dis., 3, 56.

STRONG, J. P., WAINSRIGHT, J. \& McGILL, H. C. (1959). Circulation, 20, 1118.

TECHNICAL GROUP of the Committee on Lipoproteins and Atherosclerosis, (1956). Circulation, 14, 691. 
WALKER, A. R. P. \& ARVINDSSON, U. B. (1954). J. Clin. Invest. 33, 1358. , (1963). S. Afr. Med. J., 37, 1155.

WATSON-WILLIAMS, E. J. (1965). Personal communication. Quoted by Brews, St. J. D. \& Edington, G. M. in "Abrnomal haemoglobins in Africa”. Ed. by J. H. P. Jonxis, Oxford, Blackwell.

WILLIAMS, D. (1961) in Scientific aspects of Neurology. Ed. by H. Garland, Edinburg, Livingstone.

WILLIAMS, D. \& WILSON, T. G. (1962). Brain, 85, 741.
WILliAMS, O. A. \& RESCH, A. (1969). Neurology (Minneap.) In press.

YATES, P. O. (1964). Lancet, 1, 65.

The above two papers were originally published in the West African Medical Journal (WAMJ) as cited below: 1. Odeku, E. L., Beginnings of Neurosurgery at the University of Ibadan. WAMJ (1965) 14; 85-89

2. Osuntokun, B. O. Odeku, E. L. and Adeloye, A., Cerebrovascular Accidents in Nigerians: A Study of 348 patients. WAMJ (1969) 18; 160-173.

WAMJ owns the copyright to these articles. , (1964). Brit. Med. J., 1, 84. 